NBER WORKING PAPER SERIES

\title{
HOW PERSISTENT LOW EXPECTED RETURNS ALTER OPTIMAL LIFE CYCLE SAVING, INVESTMENT, AND RETIREMENT BEHAVIOR
}

\author{
Vanya Horneff \\ Raimond Maurer \\ Olivia S. Mitchell
}

Working Paper 24311

http://www.nber.org/papers/w24311

\author{
NATIONAL BUREAU OF ECONOMIC RESEARCH \\ 1050 Massachusetts Avenue \\ Cambridge, MA 02138 \\ February 2018
}

The authors are grateful for research support from the German Investment and Asset Management Association (BVI), the SAFE Research Center funded by the State of Hessen, and the Pension Research Council/Boettner Center at The Wharton School of the University of Pennsylvania. We also thank the initiative High Performance Computing in Hessen for granting us computing time at the LOEWE-CSC and Lichtenberg Cluster. Suggestions from Jagadeesh Gokhale were also helpful. Opinions and any errors are solely those of the authors and not of the institutions with which the authors are affiliated, or any individual cited. The views expressed herein are those of the authors and do not necessarily reflect the views of the National Bureau of Economic Research.

At least one co-author has disclosed a financial relationship of potential relevance for this research. Further information is available online at http://www.nber.org/papers/w24311.ack

NBER working papers are circulated for discussion and comment purposes. They have not been peerreviewed or been subject to the review by the NBER Board of Directors that accompanies official NBER publications.

(C) 2018 by Vanya Horneff, Raimond Maurer, and Olivia S. Mitchell. All rights reserved. Short sections of text, not to exceed two paragraphs, may be quoted without explicit permission provided that full credit, including $\odot$ notice, is given to the source. 
How Persistent Low Expected Returns Alter Optimal Life Cycle Saving, Investment, and

Retirement Behavior

Vanya Horneff, Raimond Maurer, and Olivia S. Mitchell

NBER Working Paper No. 24311

February 2018, Revised August 2018

JEL No. D14,D15,D78,D91,G11,G22,H55,J14,J26

\begin{abstract}
$\underline{\text { ABSTRACT }}$
This paper explores how an environment of persistent low returns influences saving, investing, and retirement behaviors, as compared to what in the past had been thought of as more "normal" financial conditions. Our calibrated lifecycle dynamic model with realistic tax, minimum distribution, and Social Security benefit rules produces results that agree with observed saving, work, and claiming age behavior of U.S. households. In particular, our model generates a large peak at the earliest claiming age at 62, as in the data. Also in line with the evidence, our baseline results show a smaller second peak at the (system-defined) Full Retirement Age of 66. In the context of a zero return environment, we show that workers will optimally devote more of their savings to non-retirement accounts and less to 401(k) accounts, since the relative appeal of investing in taxable versus tax-qualified retirement accounts is higher in a low return setting. Finally, we show that people claim Social Security benefits later in a low interest rate environment.
\end{abstract}

Vanya Horneff

Goethe University Frankfurt

Finance Department

Theodor-W. Adorno Platz 3

House of Finance

60323 Frankfurt

Germany

vhorneff@finance.uni-frankfurt.de

Raimond Maurer

Goethe University Frankfurt

Finance Department

Theodor-W. Adorno Platz 3

60323 Frankfurt am Main

Germany

maurer@finance.uni-frankfurt.de
Olivia S. Mitchell

University of Pennsylvania

The Wharton School

3620 Locust Walk, St 3000 SH-DH

Philadelphia, PA 19104-6302

and NBER

mitchelo@wharton.upenn.edu 


\section{How Persistent Low Expected Returns \\ Alter Optimal Life Cycle Saving, Investment, and Retirement Behavior}

Low interest rates are now a reality not only in the United States but around the world, as recently noted by former Federal Reserve Chairman Ben Bernanke (2015). In the US, the government can borrow for a decade at a yield of only 2.3\%, while in Switzerland, government bond yields are negative out to 50 years (Lewin, 2016; Zeng, 2017). Our Chapter explores how this environment of persistent low returns is likely to influence saving, investing, and retirement behaviors, compared to what in the past were deemed more 'normal' financial conditions.

The persistence of low returns has implications for many aspects of the financial market. In the case of defined benefit (DB) pensions, a permanently low interest rate can render the DB plan underfunded, particularly when actual returns prove to be below those assumed when discounting future payouts. In the case of defined contribution (DC) plans, which are now the norm in the United States, the implications are more complex. In particular, persistent low returns can compel workers to save more and invest differently when allocating across stocks and bonds. Moreover, the low interest rate environment can also change retirement decisions, especially regarding how long to work and when to claim Social Security benefits.

This Chapter builds on a number of studies using a life cycle framework to model and evaluate how individuals respond to a range of environmental shocks. The workhorse model of Cocco, Gomes, and Maenhout (2015) and Gomes and Michaelides (2005) was extended by Love (2010) and Hubener, Maurer and Mitchell (2016), who showed how family shocks due to changes in marital status and children alter optimal consumption, insurance, asset allocation, and retirement patterns. In Horneff, Maurer, Mitchell, and Rogalla (2015), we demonstrated how capital market surprises can influence saving and portfolio allocation patterns, and in Chai, Horneff, Maurer, and Mitchell (2011) we showed how flexible work patterns can help people hedge both earnings and capital market risk. In the present Chapter, we evaluate how people might optimally respond to a persistently low return environment by adjusting their 
consumption, saving, investment, and retirement patterns compared to what used to be perceived as the "normal" environment. Our Chapter therefore builds on and extends the recent life cycle model developed by Horneff, Maurer, and Mitchell (2016). In contrast to that study, we do not include annuity purchases but we do allow flexible work effort and endogenous claiming of Social Security benefits. ${ }^{1}$

In what follows, we develop and calibrate a life cycle model that embeds stock market and labor market uncertainty, as well as stochastic mortality. We also incorporate U.S. tax rules and minimum distribution requirements for 401(k) plans, as well as real-world Social Security benefit formulas. We then show that our calibrated lifecycle dynamic model produces realistic results that agree with observed saving, work, and claiming age patterns of U.S. households. In particular, our model generates a large peak at the earliest benefit claiming age at 62, as in the data. Also in line with the evidence, our baseline results show a smaller second peak at the (system-defined) Full Retirement Age of 66. In the context of a zero return environment, we show that workers devote more of their savings to non-retirement accounts and less to 401(k) accounts since the relative appeal of investing into taxable versus tax-qualified retirement accounts is higher in a low return setting. Finally, we show that people claim Social Security benefits later in a low interest rate environment. A short discussion concludes.

\section{The Consumer's Lifecycle Problem: Model and Calibration}

In this section we build and calibrate a dynamic consumption and portfolio choice model for utility-maximizing individual over the life cycle.

Preferences. We work in discrete time and assume that the individual's decision period starts at $t=1$ (age of 25) and ends at $T=76$ (age 100); accordingly, each period corresponds to one year. The household's has an uncertain lifetime whereby the probability to survive from $t$

\footnotetext{
${ }^{1}$ We also provide a theoretical backing for the empirical claiming age patterns identified by Shoven and Slavov (2012, 2014).
} 
until the next year $t+1$ is denoted by $p_{t}$. Preferences in each period is represented by a Cobb Douglas function $u_{t}\left(C_{t}, l_{t}\right)=\frac{\left(C_{t} l_{t}^{\alpha}\right)^{1-\rho}}{1-\rho}$ based on current consumption $C_{t}$ and leisure time $l_{t}$ normalized as a fraction of total available time. The parameter $\alpha$ measures leisure preferences, $\rho$ denotes relative risk aversion and $\beta$ is the time preferences factor. The recursive definition of the value function is given by:

$$
J_{t}=\frac{\left(C_{t} l_{t}^{\alpha}\right)^{1-\rho}}{1-\rho}+\beta E_{t}\left(p_{t} J_{t+1}\right)
$$

with terminal utility $J_{T}=\frac{\left(C_{T} l_{T}^{\alpha}\right)^{1-\rho}}{1-\rho}$ and $l_{t}=1$ after retirement. Following prior research (Horneff et al. 2016), the baseline calibration sets $\rho=5$ and $\beta=0.96$ for both males and females. The survival rates entering the value function are taken from the US Population Life Table (Arias 2010). We calibrate the leisure parameter $\alpha$ in such a way that our results match empirical claiming rates reported by the US Social Security Administration. This matching procedure produces leisure preference parameters of $\alpha=0.9$ for males and $\alpha=1.1$ for females.

Time budget, labor income, and Social Security retirement benefits. Our model allows for flexible work effort and retirement ages. The worker has the opportunity to allocate up to (1 $\left.l_{t}\right)=0.6$ of his available time budget (assuming 100 waking hours per week and 52 weeks per year) to paid work. Depending on his work effort, the uncertain yearly pre-tax labor income is given by:

$$
Y_{t+1}=\left(1-l_{t}\right) \cdot w_{t} \cdot P_{t+1} \cdot U_{t+1}
$$

Here $w_{t}$ is a deterministic wage rate component, which depends on age, education, sex, and if the individual works overtime, full time, or part time. The variable $P_{t+1}=P_{t} \cdot N_{t+1}$ is the permanent component of wage rates with independent lognormal distributed shocks $N_{t} \sim L N\left(-0.5 \sigma_{\mathrm{P}}^{2}, \sigma_{P}^{2}\right)$ with a mean of one and volatility of $\sigma_{P}^{2}$. In addition $U_{t} \sim L N\left(-0.5 \sigma_{\mathrm{U}}^{2}, \sigma_{U}^{2}\right)$ is a transitory shock with volatility $\sigma_{U}^{2}$ and uncorrelated with $N_{t}$. 
The wage rate calibration builds on Horneff, Maurer, and Mitchell (2016), who estimated the deterministic component of the wage rate process $w_{t}^{i}$ and the variances of the permanent and transitory wage shocks $N_{t}^{i}$ and $U_{t}^{i}$ using the 1975-2013 waves of the PSID. ${ }^{2}$ These are estimated separately by sex and by educational level, where the latter groupings are less than High School, High School graduates, and at least some college $\left(<\mathrm{HS}\right.$, HS, Coll $+{ }^{3}{ }^{3}$

Between ages 62 and 70, the worker can retire from work and claim Social Security benefits, the latter of which depend on his average lifetime 35 best years of earnings. If the individual claims benefits before (after) the system-defined Normal Retirement Age of 66, then his lifelong Social Security benefits will be reduced (increased) according to pre-specified factors. If the individual works beyond age 62, we require that he devote at least a minimum effort of at least one hour per week; also, overtime work is excluded (i.e. $0.01 \leq\left(1-l_{t}\right) \leq$ $0.4)$.

Wealth dynamics during the work life. During the work life, the individual has the opportunity to use current cash on hand for consumption and investments. Some portion $A_{t}$ of the worker’s pre-tax salary $Y_{t}$ (up to a limit of $\$ 18000$ per year) can be invested into a taxqualified 401(k)-retirement plan of the EET type. ${ }^{4}$ That is, contributions into the account and investment earnings on account assets are tax-exempt, $(\mathrm{E})$, while withdrawals are taxed $(\mathrm{T})$. In addition, a worker can invest outside his retirement plan in risky stocks $S_{t}$ and riskless bonds $B_{t}$. As such, his cash on hand $X_{t}$ in each year is given by

$$
X_{t}=C_{t}+S_{t}+B_{t}+A_{t}
$$

where the usual constraints $C_{t}, A_{t}, S_{t}, B_{t} \geq 0$ apply. One year later, his cash on hand is given by the value of stocks (bonds) having earned an uncertain (riskless) gross return of $R_{t+1}\left(R_{f}\right)$, plus

\footnotetext{
2 Dollar values are given in 2013 terms.

${ }^{3}$ Details are given in Horneff, Maurer and Mitchell (2016), Table A1, Appendix A.

${ }^{4}$ This approach to retirement benefit taxation is therefore similar to how regular defined benefit and defined contribution plan payments are handled under US tax law. We abstract here from Roth 401(k)s.
} 
income from work (after housing expenses $h_{t}$ ), plus withdrawals $\left(W_{t}\right)$ from the 401(k) plan, minus any federal/state/city Taxes and Social Security $\operatorname{Tax}_{t+1}$ contributions:

$$
X_{t+1}=S_{t} R_{t+1}+B_{t} R_{f}+Y_{t+1}\left(1-h_{t}\right)+W_{t}-\operatorname{Tax}_{t+1}
$$

We model housing costs $h_{t}$ as in Love (2010). Our "baseline" financial market parameterizations assume a risk-free interest rate of $1 \%$, and an equity risk premium of $4 \%$ with a return volatility of $18 \%$. In simulations below of the low-yield environment, we vary these assumptions.

During his work life, the individual pays taxes $\left(\operatorname{Tax}_{t+1}\right)$ which reduce his cash on hand available for consumption and investments. ${ }^{5}$ These include the labor income tax at a rate of 11.65\% (the sum of 1.45\% Medicare, 4\% City and State Tax and 6.2\% Social Security tax). Also under the US progressive tax system, the individual must also pay taxes on labor income as well as on withdrawals from tax-qualified retirement plans (including a $10 \%$ penalty tax for withdrawals before age 60), and on returns on stocks and bonds held outside the tax-qualified retirement account. If his cash on hand falls below $X_{t+1} \leq \$ 5,950$ p.a. (an amount also exempt from income taxes), he is supported by the state so he has a minimum wealth level of $\$ 5,950$ for the next year.

Prior to the endogenous retirement age $t=K$, the assets in his tax-qualified retirement plan are invested in bonds earning a risk-free gross (pre-tax) return of $R_{f}$ and risky stocks with an uncertain gross return of $R_{t}$. The total value $\left(F_{t+1}^{401(k)}\right)$ of the $401(\mathrm{k})$ assets at time $t+1$, usually held in a 401(account), is determined by the previous period's value minus any withdrawals $\left(W_{t} \leq F_{t}^{401(k)}\right)$, plus additional contributions $\left(A_{t}\right)$, and returns from stocks and bonds:

\footnotetext{
${ }^{5}$ For details, see Horneff, Maurer and Mitchell (2016).
} 


$$
\begin{aligned}
F_{t+1}^{401(k)}=\omega_{t}^{s} & \left(F_{t}^{401(k)}-\mathrm{W}_{\mathrm{t}}+A_{t}\right) \mathrm{R}_{\mathrm{t}+1} \\
& +\left(1-\omega_{t}^{S}\right)\left(F_{t}^{401(k)}-\mathrm{W}_{\mathrm{t}}+A_{t}\right) R_{f}, \text { for } t<K
\end{aligned}
$$

We posit that his DC plan assets are held in a Target Date Fund with stock exposure declining with age following the common rule $\omega_{t}^{s}=(100-\mathrm{Age}) / 100{ }^{6}$ This is a Qualified Default Investment Alternative (QDIA) as per Department of Labor regulations (US DOL 2006).

Wealth dynamics during retirement. The worker can retire and claim Social Security benefits between age 62 and 70 . After retirement at the endogenous age $K$, the individual has the opportunity to save outside the tax-qualified retirement plan in stocks and bonds:

$$
X_{t}=C_{t}+S_{t}+B_{t}
$$

His cash on hand for the next period evolves as follows:

$$
X_{t+1}=S_{t} R_{t+1}+B_{t} R_{f}+Y_{t+1}\left(1-h_{t}\right)+W_{t}-\operatorname{Tax}_{t+1} .
$$

Old age retirement benefits provided by Social Security are determined by the worker's Primary Insurance Amount (PIA), which depend on his 35 best years of earnings. ${ }^{7}$ Social Security payments $\left(Y_{t+1}\right)$ in retirement $(t \geq K)$ are given by:

$$
Y_{t+1}=P I A_{K} \cdot \lambda_{K} \cdot \varepsilon_{t+1} .
$$

Here, $\lambda_{K}$ is the adjustment factor for claiming before or after the normal retirement age, which is equal to age $66 .^{8}$ The variable $\varepsilon_{t}$ is a transitory shock $\varepsilon_{t} \sim \operatorname{LN}\left(-0.5 \sigma_{\varepsilon}^{2}, \sigma_{\varepsilon}^{2}\right)$, which reflects out-of-pocket medical and other expenditure shocks in retirement (as in Love 2010). During

\footnotetext{
${ }^{6}$ This was suggested by Malkiel (1996), for instance.

7 The benefit formula is a piece-wise linear function of the Average Indexed Monthly Earnings providing (as of 2013) a replacement rate of $90 \%$ up to a first bend point (\$791), 32\% between the first and the second bend point \$4768), and $15 \%$ above that. See US SSA (nd_d).

${ }^{8}$ The factors we use are 0.75 (claiming age 62), 0.8 (claiming age 63), 0.867 (claiming age 64), 0.933 (claiming age 65), 1.00 (claiming age 66), 1.08 (claiming age 67), 1.16 (claiming age 68), 1.24 (claiming age 69), and 1.32 (claiming age 70). See US SSA (nd_a, c).
} 
retirement, benefits payments from Social Security are partially taxed ${ }^{9}$ by the individual federal income tax rate as well as the $1.45 \%$ Medicare and $4 \%$ city and state taxes.

We model the 401(k) plan payouts as follows:

$$
\begin{aligned}
F_{t+1}^{401(k)}=\omega_{t}^{s}( & \left.F_{t}^{401(k)}-\mathrm{W}_{\mathrm{t}}\right) \mathrm{R}_{\mathrm{t}+1} \\
& +\left(1-\omega_{t}^{S}\right)\left(F_{t}^{401(k)}-\mathrm{W}_{\mathrm{t}}\right) R_{f}, \quad \text { for } t<K
\end{aligned}
$$

Under US law, plan participants must take retirement account payouts from age 70 onwards, according to the Required Minimum Distribution rules $(m)$ specified by the Internal Revenue Service (IRS nd). Accordingly, withdrawals from the retirement account must take into account the following constraints: $F_{t}^{401(k)} m \leq W_{t}<F_{t}^{401(k)}$.

\section{Baseline Results in a “Normal” Interest Rate Environment}

Next we evaluate, in a "normal” interest rate world, how people would optimally choose their consumption, work effort, the claiming age for Social Security benefits, investments in as well as withdrawals from tax-qualified 401(k)-plans, and investments in stocks and bonds. We posit that households maximize the value function (1) under budget restrictions. This optimization problem cannot be solved analytically, so it requires a numerical procedure using dynamic stochastic programming. To generate optimal policy functions, in each period $t$ we discretize the space in four dimensions $30(X) \times 20\left(F^{401(k)}\right) \times 8(P) \times 9(K)$, with $X$ being cash on hand, $F^{401(k)}$ assets held in the $401(\mathrm{k})$ retirement plan, $\mathrm{P}$ permanent income, and $K$ the claiming age. Next, we simulate 100,000 independent life cycles based on optimal feedback controls for each of the six population subgroups of interest (male/female with $<\mathrm{HS}$, HS, and Coll+). We then aggregate the subgroups to obtain national mean values using weights from the National Center on Education Statistics (2012). Specifically, the weights are 50.7\% female (and 62\%

\footnotetext{
${ }^{9}$ For tax rules for Social Security see US SSA (nd_b). Based on the combined income up to 85\% of Social Security can be taxed for households with high income additional to Social Security benefits. Yet because of quite generous exemptions, most households receive their Social Security benefits tax-free (see Horneff, Maurer, Mitchell 2016).
} 
with Coll+, 30\% with HS, and 8\% with <HS), and 49.3\% male (and 60\% with Coll+, 30\% HS and $10 \%<\mathrm{HS})$.

Figure 1 reports results for our baseline calibration assuming a risk-free interest rate of $1 \%$, and an expected return on stocks of $5 \%$ with a volatility of $18 \%$. The life cycle graphs appear in the upper panels, while Social Security benefit claiming behavior appears in the lower panels. Moreover, results for men appear on the left, and for women on the right.

\section{Figure 1 here}

Panels A and B demonstrate that, during the work life, labor income substantially exceeds consumption. This is partly due to the fact that we show pre-tax income, so after income taxes, net labor income tracks consumption more closely. During the worker's first decade in the job market, he saves only a small amount due to the fact that he is liquidity-constrained when young. (The worker also cannot increase consumption by borrowing against future labor income). From age 35 onward, savings rise, especially in the 401(k) plan retirement plan to peak around age 59. Thereafter, he systematically draws down assets from the plan, since after age 59.5, he need no longer pay the 10 percent penalty tax for early withdrawals. In retirement, between age 62 and 70, his Social Security income falls below average consumption, with the difference financed by retirement plan withdrawals.

For women, though their labor income is lower than for males, they still accumulate almost the same amount of retirement plan assets. This can be explained by the fact that the average life expectancy for women is substantially higher than for men, so women must save more to maintain desired consumption levels over a longer period. For example, at age 25 (the starting point of our lifecycle model), the life expectancy of females is age 81 , or about 4.5 years more than for males. Both women's and men's consumption drops slightly during the retirement period, which is in line with both empirical evidence and theoretical lifecycle 
literature (Chai et al. 201, Battistin et al. 2009). This can be explained by the sharp increase in leisure time after people claim Social Security benefits. ${ }^{10}$

Panels C and D of Table 1 reveal that the Social Security claiming patterns generated by our model align closely with empirical claiming rates reported by the US Social Security Administration. ${ }^{11}$ That is, our model generates a large peak at the earliest claiming age at 62, whereas as in the data, about $45 \%$ of workers claim their benefits at this point. Additionally, and also in line with the evidence, our baseline results show a smaller second peak at the (system-defined) Full Retirement Age of 66; here about 15\% of workers claim benefits for the first time. Overall, the results of our baseline calibration confirm that our model produces realistic results that agree with observed work, saving, and claiming age behavior of U.S. households.

\section{Understanding the Impact of Interest Rates}

Having provided the baseline "normal” environment results, we next evaluate what changes in a different interest rate environment. To this end we examine two experiments. First we reduce the (real) risk free interest from $1 \%$ to $0 \%$, and second, we increase the real interest rate to $2 \%$. (In both cases we keep the equity risk premium at $4 \%$ ). Table 1 reports results for men and women, separately.

Table 1 here

In this Table, we report the rates at which people claim their Social Security benefits by age, as well as the overall claiming age. One key finding is that the lower is the risk free interest rate the higher are claiming ages. In other words, when the long term interest rate falls to zero, women claim about 0.4 years later, and men almost a full year later. Another point to note is that claiming at the earliest possible age of 62 declines quite notably, more so for men but also

\footnotetext{
10 This pattern conforms with evidence on expenditure drops after retirement found by Aguiar and Hurst (2005).

${ }^{11}$ For instance, see the US Social Security Administration. (2015), Table 6.B5. We adjust their data to omit disability conversions at age 65 and scale the other age brackets so they sum to $100 \%$.
} 
for women. We explain this by noting that, when expected returns are high, the worker can claim early Social Security benefits without needing to withdraw as much from his retirement assets which continue to earn higher returns for a while longer. But when the real interest rate is low, a worker can delay claiming Social Security in exchange for higher lifelong benefits, and the cost of taking more from his retirement count to support consumption is lower. This is in line with Shoven and Slavov (2014) who argued that, by delaying claiming, people can maximize the actuarial net present value of their lifetime Social Security benefits in times of low returns. By contrast when returns are higher, the net present value of benefits is maximized by claiming early. Evidence from Shoven and Slavov (2012) and Cahill, Giandrea, and Quinn (2015) also suggests that low (high) interest rates result in later (earlier) claiming ages. Accordingly, our results are in line with empirical evidence.

Table 2 shows how wealth accumulation changes under the two interest rate regimes, both inside and outside the 401(k) plan. In the low return environment, workers build up less wealth in their retirement plans. For instance, when the safe yield is $0 \%$, middle aged women (age 55-64) optimally accumulate an average of about $\$ 88,200$ in their $401(\mathrm{k})$ plans, while in the $2 \%$ yield scenario, they average one-third more, or $\$ 117,700$ at the same point in their life cycle. Middle-aged men accumulate $\$ 83,200$ in the Zero-rate environment, and 45\% more $(\$ 120,600)$ in the $2 \%$ interest rate scenario. Interestingly, the opposite pattern applies to assets held outside the tax-qualified retirement plans. That is, women age 45-54 hold \$16,600 in liquid stocks and bonds when the interest rate is Zero, but only $\$ 9,800$ in the two percent interest rate scenario. The same effect also applies to males.

Table 2 here

The divergent impact of low versus high interest rates on asset holdings inside versus outside tax-qualified retirement plans can be explained as follows. When the interest rate is low, people work fewer hours per week early in life, compared to workers in the higher interest environment. For example, women work two hours per week less between age 25-60 than they 
do in the two percent interest rate scenario. ${ }^{12}$ The reason is that, in the higher return scenario, it is more attractive to build up savings early in life as these can grow at the higher rate. More work effort then generates higher labor income, and because of the progressive tax system, this results in a larger allocations to the tax-exempt retirement accounts. In addition, returns earned on assets held inside the 401(k) plan are tax-free. This second advantage is, of course, smaller in a zero return environment. Accordingly, when interest rates are low (high), workers devote more (less) of their savings to non-retirement accounts.

\section{Conclusions}

Financial writers have noted with concern that the long-term impact of very low interest rates has been to drive some investors to "hunt for yield," taking on riskier investments (Bryan 2016). Yet little academic research has focused on how persistent low returns would optimally shape workers' and retirees' decisionmaking regarding accumulation and retirement patterns. Our lifecycle model integrates realistic tax, Social Security, and minimum distribution rules, as well as uncertain income, stock returns, and mortality. The baseline calibration generates a large peak at the earliest claiming age at 62, in line with the evidence. Additionally, baseline results produce a smaller second peak at the (system-defined) Full Retirement Age of 66. Overall, the results of the baseline calibration confirm that our model produces realistic results that agree with observed work, saving, and claiming age behavior of American households.

The results of alternative interest rate regimes are also quite informative. One sensible result is that people are predicted to save less during periods of low returns. Second, people finance consumption relatively early in retirement by drawing down their 401(k) assets sooner. Third, low rates also change where people save. During low-return periods, workers save less in tax-qualified accounts and more outside tax-qualified plans, until retirement. The reason is

\footnotetext{
12 This numbers are not reported in Tables 1 and 2; computations available on request.
} 
that the tax advantages of saving in 401(k) plans are relatively less attractive, inasmuch as the gain from saving in pretax plans is lower, and because the return on assets in the retirement account are lower in a low return environment. And fourth, we find that low interest rates drive workers to claim Social Security benefits later, so they can take advantage of the relatively high payoff to deferring retirement under current rules. In this way, we confirm that tax and Social Security claiming rules have a powerful effect on how households are able to adjust to financial market fluctuations. 


\section{References}

Aguar, M. and E. Hurst. (2005). Consumption vs. Expenditure. Journal of Political Economy 113(5): 919-948.

Arias, E. (2010). United States Life Tables, 2005. National Vital Statistics Reports 58(10), US National Center for Health Statistics: Hyattsville, Maryland.

Battistin, E., A. Brugiavini, E. Rettore, and G. Weber. (2009). The Retirement Consumption Puzzle: Evidence from a Regression Discontinuity Approach. American Economic Review 99(5): 2209-2226.

Bernanke, B. (2015). Why Are Interest Rates So Low? Brookings Institution Report. March 30. https://www.brookings.edu/blog/ben-bernanke/2015/03/30/why-are-interest-rates-so-low/

Bryan, B. 2016. Central Bankers are Doing Something That Hasn't Happened in 5,000 years and Drastically Changing the World Economy. BusinessInsider.com. August 19. http://www.businessinsider.com/record-low-interest-rate-impact-2016-8

Cahill, K., M. Giandrea, and J. Quinn. (2015). Evolving Patterns of Work and Retirement. In The Handbook of Aging and the Social Sciences, 8th ed. L. George and K.Ferraro, Eds. London UK: Academic Press: 271-291.

Carroll, C. D. and A. A. Samwick. (1997). The Nature of Precautionary Wealth. Journal of Monetary Economics 40(1): 41-71.

Chai, J., W. Horneff, R. Maurer, and O. S. Mitchell. (2011). Optimal Portfolio Choice over the Life Cycle with Flexible Work, Endogenous Retirement, and Lifetime Payouts. Review of Finance 15(4): 875-907.

Cocco, J., F. Gomes, and P. Maenhout. (2005). Consumption and Portfolio Choice over the Life Cycle. Review of Financial Studies 18(2): 491-533.

Gomes, F., and A. Michaelides. (2005). Optimal Life-Cycle Asset Allocation: Understanding the Empirical Evidence. Journal of Finance 60(2): 869-904.

Gomes, F. J., L. J. Kotlikoff, and L. M. Viceira. (2008). Optimal Life-Cycle Investing with Flexible Labor Supply: A Welfare Analysis of Life-Cycle Funds. American Economic Review: Papers \& Proceedings 98(2): 297-303.

Gomes, F. J., and A. Michaelides. 2005. Optimal Life-Cycle Asset Allocation: Understanding the Empirical Evidence. The Journal of Finance 60(2):869-904.

Gomes, F., A. Michaelides, and V. Polkovnichenko (2009). Optimal Savings with Taxable and Tax-Deferred Accounts. Review of Economic Dynamics 12(4): 718-735.

Horneff, V., R. Maurer, O.S. Mitchell, and R. Rogalla. (2015). Optimal Life Cycle Portfolio Choice with Variable Annuities Offering Liquidity and Investment Downside Protection. Insurance: Mathematics and Economics 63(1): 91-107. 
Horneff, V., R. Maurer, and O.S. Mitchell. (2016). Putting the Pension Back in 401(k) Plans: Optimal versus Default Longevity Income Annuities. NBER Working Paper 22717

Hubener, A., R. Maurer, and O. S. Mitchell. (2016). How Family Status and Social Security Claiming Options Shape Optimal Life Cycle Portfolios. Review of Financial Studies 29(4): 937-978.

Internal Revenue Service (IRS 2012a). Form 1040 (Tax Tables): Tax Tables and Tax Rate Schedules. Downloaded 03/12/2013. www.irs.gov/pub/irs-pdf/i1040tt.pdf.

Internal Revenue Service (IRS 2014). Lifetime Income Provided through Target Date Funds in Section 401(k) Plans and Other Qualified Defined Contribution Plans. IRS Notice 201466. https://www.irs.gov/pub/irs-drop/n-14-66.pdf

Internal Revenue Service (IRS 2012b). Retirement Plan and IRA Required Minimum Distributions FAQs. https://www.irs.gov/Retirement-Plans/Retirement-Plans-FAQsregarding-Required-Minimum-Distributions.

Lewin, J. (2016). Swiss Bond Yields Now Negative Out to 50 Years. FT.com, July 5. https://www.ft.com/content/2ae4237a-2d3e-33dd-b9e0-120c4a93a29c

Love, D.A. (2007). What Can Life-Cycle Models Tell Us about 401(k) Contributions and Participation? Journal of Pension Economics and Finance 6 (2): 147-185.

Love, D.A. (2010). The Effects of Marital Status and Children on Savings and Portfolio Choice. Review of Financial Studies 23(1): 385-432.

Malkiel, B.G. (1996). A Random Walk Down Wall Street: Including a Life-Cycle Guide to Personal Investing. $6^{\text {th }}$ ed. New York: Norton.

Poterba, J., S. Venti, and D. Wise (2000). Saver Behavior and 401(k) Retirement Wealth. American Economic Review 90(2): 297-302.

Shoven, J.B., and S. N. Slavov. (2014). Does it pay to delay social security? Journal of Pension Economics and Finance 13 (2): 121-144.

Shoven, J.B., and S. N. Slavov. (2012). The Decision to Delay Social Security Benefits: Theory and Evidence, NBER Working Paper 17866.

US Department of Labor (US DOL). (2016). Economic News Release Table A-4. Employment Status of the Civilian Population 25 Years and Over by Educational Attainment.

US Department of Labor (US DOL). (2006). Fact Sheet: Default Investment Alternatives under Participant-Directed Individual Account Plans.

https://www.dol.gov/ebsa/newsroom/fsdefaultoptionproposalrevision.html

US Department of Labor (US DOL). (nd). Fact Sheet: Regulation Relating to Qualified Default Investment Alternatives in Participant-Directed Individual Account Plans. https://www.dol.gov/ebsa/newsroom/fsqdia.html 
US Social Security Administration (US SSA). (nd). Fact Sheet: Benefit Formula Bend Points. https://www.ssa.gov/oact/cola/bendpoints.html

US Social Security Administration. (2014). Annual Statistical Supplement to the Social Security Bulletin. www.ssa.gov/policy/docs/statcomps/supplement/2014.

US Social Security Administration. (2015). Annual Statistical Supplement to the Social Security Bulletin, 2015 (Table 6.B5).

Zeng, M. (2017). US 10-Year Note Yield Hits Low for the Month. WallStreetJournal.com. March 31. https://www.wsj.com/articles/u-s-bonds-rebound-from-earlier-losses1490108750?tesla $=y$ 
Figure 1: Life Cycle Behavior and Social Security Claiming Patterns for Males and Females

A

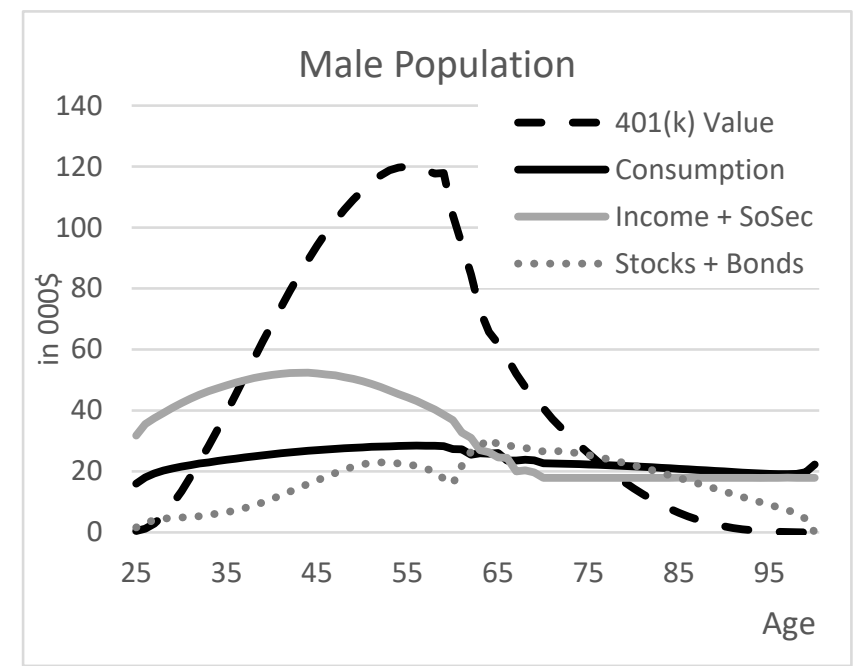

C

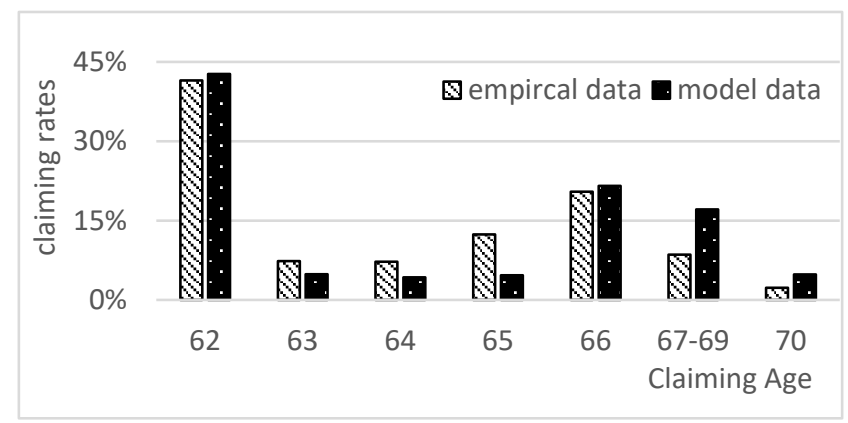

B

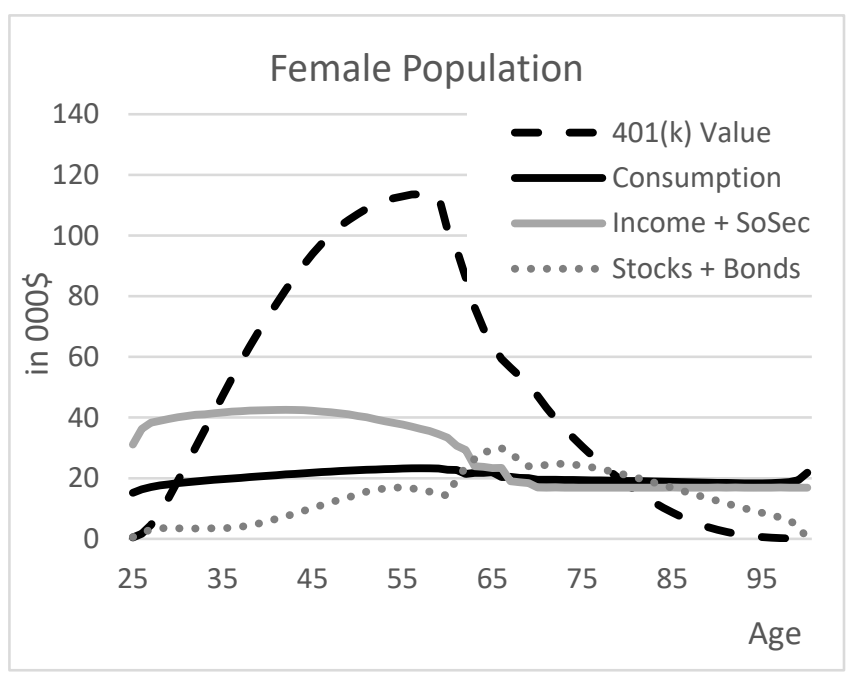

D

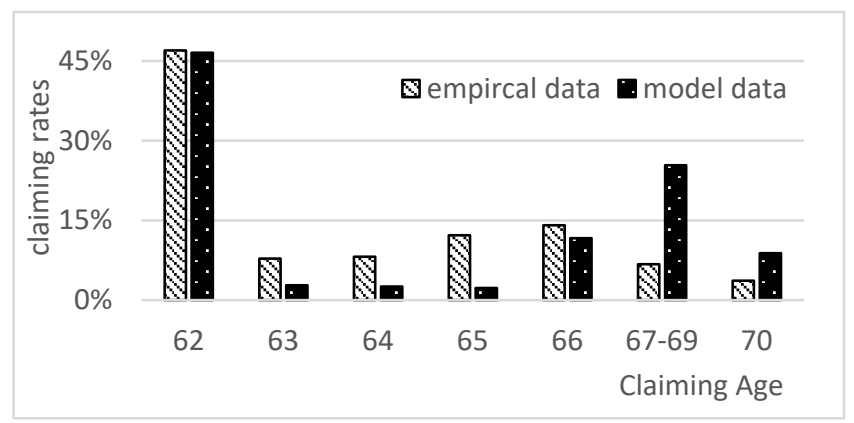

Notes: The top two panels show expected life cycle patterns for males and females (consumption, income, assets in 401(k) tax-qualified plans, and bonds/stocks. The lower two panels present claiming rates generated by our life cycle models versus empirical claiming rates as reported by the US Social Security Administration for the year 2014. Expected values are calculated from 100,000 simulated lifecycles based on optimal feedback controls. Results for the entire female (male) population are computed using income profile for three education levels: $62 \%+C o l l ; 30 \% \mathrm{HS} ; 8 \%<\mathrm{HS}(60 \%+\mathrm{Coll} ; 30 \%$ HS; $10 \%<$ HS). Parameters used for the baseline calibration are as follows: risk aversion $\rho=5$; time preference $\beta=0.96$; leisure preference $\alpha=0.9$ (female) $\alpha=1.1$ (male); endogenous retirement age 62-70. Social Security benefits are based on average permanent income and the bend points in place in 2013; minimum required withdrawals from 401(k) plans are based on life expectancy using the IRS-Uniform Lifetime Table in 2013; tax rules for 401(k) plans are as described in Horneff (2015). The risk premium for stocks returns is $4 \%$ and return volatility $18 \%$; the risk free rate in the baseline case is $1 \%$. Source: Authors' calculations. 
Table 1: Social Security Claiming Ages for Females and Males

\begin{tabular}{|c|c|c|c|c|c|c|c|c|c|c|}
\hline \multicolumn{11}{|c|}{ Claiming rates (\%) by age } \\
\hline & 62 & 63 & 64 & 65 & 66 & 67 & 68 & 69 & 70 & $\begin{array}{c}\text { Average } \\
\text { Claiming Age }\end{array}$ \\
\hline \multicolumn{11}{|l|}{ Panel A: Female } \\
\hline $0 \%$ Interest Rate & 46.1 & 2.1 & 2.2 & 3.1 & 7.2 & 5.5 & 9.8 & 10.7 & 13.3 & 65.1 \\
\hline $1 \%$ Interest Rate & 46.6 & 2.8 & 2.6 & 2.3 & 11.6 & 7.4 & 10.0 & 7.9 & 8.8 & 64.8 \\
\hline $2 \%$ Interest Rate & 47.6 & 2.5 & 2.4 & 2.4 & 13.1 & 9.9 & 9.6 & 5.4 & 6.9 & 64.7 \\
\hline \multicolumn{11}{|l|}{ Panel B: Male } \\
\hline $0 \%$ Interest Rate & 39.9 & 3.5 & 4.7 & 4.6 & 16.3 & 13.1 & 7.2 & 5.2 & 5.5 & 64.8 \\
\hline $1 \%$ Interest Rate & 42.7 & 4.9 & 4.3 & 4.7 & 21.6 & 11.3 & 3.4 & 2.4 & 4.8 & 64.5 \\
\hline $2 \%$ Interest Rate & 49.6 & 5.6 & 4.5 & 6.2 & 24.7 & 4.0 & 1.5 & 1.4 & 2.6 & 63.9 \\
\hline
\end{tabular}

Notes: We report the expected claiming rates for three different interest rate levels by age, derived from 100,000 simulated lifecycles based on optimal feedback controls from the life cycle model. The assumed risk premium for stock returns is $4 \%$ and return volatility $18 \%$. For other parameters see Figure 1. Source: Authors' calculations.

Table 2: Lifecycle Asset Accumulation Patterns for Females and Males

\begin{tabular}{|c|c|c|c|c|c|c|}
\hline & \multicolumn{3}{|c|}{ Female } & \multicolumn{3}{|c|}{ Male } \\
\hline & $\begin{array}{c}0 \% \\
\text { Interest } \\
\text { Rate }\end{array}$ & $\begin{array}{c}1 \% \\
\text { Interest } \\
\text { Rate }\end{array}$ & $\begin{array}{c}2 \% \\
\text { Interest } \\
\text { Rate } \\
\end{array}$ & $\begin{array}{c}0 \% \\
\text { Interest } \\
\text { Rate }\end{array}$ & $\begin{array}{c}1 \% \\
\text { Interest } \\
\text { Rate }\end{array}$ & $\begin{array}{c}2 \% \\
\text { Interest } \\
\text { Rate }\end{array}$ \\
\hline \multicolumn{7}{|c|}{ Panel A: 401(k) Assets in $\$ 000$} \\
\hline Age $25-34$ & 16.8 & 18.1 & 21.1 & 9.9 & 13.6 & 14.9 \\
\hline Age $35-44$ & 57.9 & 70.0 & 80.2 & 48.6 & 65.0 & 70.3 \\
\hline Age 45-54 & 92.4 & 105.0 & 124.4 & 91.4 & 109.2 & 122.7 \\
\hline Age 55-64 & 88.2 & 99.5 & 117.7 & 83.2 & 101.6 & 120.6 \\
\hline Age $65-74$ & 33.5 & 48.4 & 64.4 & 27.4 & 43.6 & 63.1 \\
\hline Age $75-84$ & 10.8 & 19.5 & 30.8 & 8.5 & 16.0 & 26.4 \\
\hline Age $85-94$ & 1.6 & 4.0 & 7.9 & 1.2 & 2.7 & 5.8 \\
\hline \multicolumn{7}{|c|}{ Panel B: Non-Qualified Assets in $\$ 000$} \\
\hline Age $25-34$ & 2.7 & 3.0 & 2.6 & 6.4 & 4.5 & 4.3 \\
\hline Age $35-44$ & 11.1 & 5.8 & 4.9 & 18.3 & 10.8 & 10.8 \\
\hline Age $45-54$ & 16.6 & 14.0 & 9.8 & 25.6 & 21.1 & 18.6 \\
\hline Age 55-64 & 16.5 & 19.3 & 16.0 & 24.7 & 22.6 & 18.3 \\
\hline Age $65-74$ & 25.3 & 25.9 & 25.3 & 28.4 & 27.2 & 25.3 \\
\hline Age $75-84$ & 19.7 & 21.2 & 21.8 & 21.1 & 22.2 & 23.3 \\
\hline Age 85-94 & 11.5 & 13.0 & 14.1 & 12.5 & 13.9 & 14.3 \\
\hline
\end{tabular}

Notes: The two panels show expected assets in tax-qualified 401(k) plans and non-qualified assets under three interest rate assumptions, for males and females by age. Expected values are based on 100,000 simulated lifecycles using optimal feedback controls from the life cycle model. The risk premium for stock returns is $4 \%$ and return volatility 18\%. Other parameters are reported in Figure 1.Source: Authors’ calculations. 